特集 2 : アフリカン・ポップスの諸相

序論 アフリカ音楽研究の梘座

広島市立大学国際学部 战 $\mathbf{A}$ 践 -

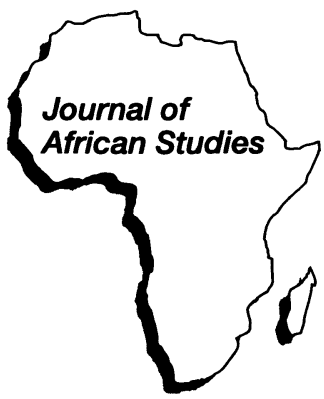

\section{1. 海外と日本の「音文化」研究}

本特集の序論として，ここでは日本であまり知られて いない海外でのアフリカ音楽研究の動向を概観すること にする。

18，19世紀にアフリカを訪れた西洋の旅行者, 探検家, 宣教師などの記録にはアフリカの音楽に関する記述が散 見される ${ }^{1)}$ 。しかし，アフリカ音楽の本格的な研究が開 始されたのは 1920 年代であった。その最も代表的な例と して, 学術誌『アフリカ』第一巻に掲載されたエーリッ ヒ・フォン・ホルンボステルの「アフリカ黒人音楽」 （Hornbostel 1928）を挙げることができる。この論文は， 今日から見るといくつかの誤った前提に基づいて書かれ てはいるが, アフリカの旋律やリズム, 声部唱法などを 音楽学的に分析した初期の学術論考の一つと言える。こ うした形式分析に重点を置いたアフリカ音楽への初期の アプローチが, じつはその後の音楽研究の展開に大きな 影響を及ぼし，ある意味でアフリカの音楽文化を包括的 に理解することを困難にした。というのは，こうした形 式分析によって西洋近代の音楽分析の基礎となった「楽 譜中心主義」の弊害がそのままアフリカ研究にもち込ま れてしまったからである。

ところが，こうした狭義での「音楽」概念から離れて 当時の状況を鳥瞰すると, アフリカにはそれ以前から 「音の文化」に関するかなり本格的な研究の流れがあっ たことがわかる。たとえば，カメルーンのドゥアラで長 期間トーキング・ドラムを研究していたベッツは， 1898 年太鼓音を言語音で表現する「太鼓音節」(Trommelsilben) 2)に関して詳細な記録を残している（Betz 1976 [1898]）。 それらの資料は，今日の音象徴性研究の観点からも大変 興味深い貴重なものである。また 1912 年にはネケスが同 じくカメルーンのヤウンデの太鼓ことばを調査し，同様
の資料を公にしている（Nekes, 1976 [1912]）。このような 研究は, しかしながらきわめて散発的なもので研究史上 主流となることはなかった。その後 20 世紀前半で大きな 成果を挙げたのは，筆者の知る限り，キャリントンの研 究 (Carrington, 1949) のみである。ここで注目すべきは， 近代的な「音楽」概念の枠外にあるこのような音の問題 に対して，近年欧米の研究者の間で関心が高まってきて いることだ。それを如実に示しているのは，1998年にイ ンディアナ大学で開催されたアメリカ民族音楽学会年次 大会での「アフリカの演奏における象徵性とアイコニシ ティ」(Symbolism and Iconicity in African Performance) と いう分科会である。ここではアフリカの口承文芸の語り に見られる音楽的要素やそこで用いられるイディオフォ ーン（擬態語，擬音語等）の詳細な分析，あるいは音象 徵性の観点からの太鼓の口唱歌（「太鼓音節」）の分析， さらに儀礼の語りにおけるパフォーマンス体験の重要性 についての分析など，さまざまな研究成果が発表された (Buckner 1998; Klassen 1998; Reily 1998; Tsukada 1998a)。と くに音象徴性の観点からの口唱歌の研究は，民族音楽学 の分野ではアフリカ以外の地域の研究において 1980 年代 後半から始まったもので (Hughes, 1989 など), アフリカ 研究におけるこの分野の最近の大きな成果はニーリーの 著書 (Neeley, 1999) に見られる。

しかしながら，このようなアフリカの「音文化」への 近年の関心や探求は, じつは欧米よりもはやく日本で始 まったということは强調しておいて良からう。 80 年代前 半の一連の川田の研究がそれである（川田, 1982, 1983, 1984）。文化人類学的発想で始まった日本のアフリカ 「音文化」研究 ${ }^{3)}$ は，言語を含むあらゆる音に関わる文化 的事象を射程に入れ，狭義での「音楽」はむしろその中 の一部と位置づけるのに対して、「音楽」研究者が中心 となって発展してきた欧米のアフリカ音楽研究は，それ らの問題を「音楽」研究の延長線上にある問題として周 縁に位置づける。また「音文化」という概念はそもそも 欧米には存在せず，その英語訳の Sound Cultureについて 
は，Natureに属する Sound Cultureに連結させた造語と して, 英語圏の研究者にはやや奇異な感じをもって受け 取られることもある。しかし，海外でのアフリカ音楽研 究が近年, 日本での「音文化」研究と明らかに接点をも ち始めているということは確実に言える。

\section{2. 音楽分析, 楽器研究, ドキュメンテーション}

さて, 再び20世紀前半のアフリカ音楽研究の動向に目 を移すと，そこで見えてくるのは，研究者の膨大なエネ ルギーが詳細な音楽分析と楽器研究に費やされてきたと いう事実である。たとえば，ホルンボステルは前述の論 文の中でアフリカのリズムの「シンコペーション」現象 を太鼓打奏の際の筋肉運動と関係づけて説明したが，こ の説の是非をめぐってはジョーンズ (Jones, 1934)，ブラ ッキング (Blacking, 1955)，さらにカウフマン（Kauffman, 1980）らによる一連の論争の系譜をたどることができる。 またアフリカのリズム研究のすでに「古典」となってい るジョーンズの著作（Jones, 1959）を頂点に，「解釈論」 としてのアフリカ・リズム論の展開は, その後チェル, フ（Chernoff, 1979）を経てアロム (Arom, 1991), アガウ (Agawu, 1995)，テンパリー（Temperley, 2000）など, 細々とではあるが今日に至るまで続いている。また，ア フリカの「ハーモニー」 ${ }^{4}$ 現象に焦点を当てた分析もとく に 70 年代まで活発であった。前述のホルンボステルの論 文を皮切りにハーモニーについては起源論（Kirby, 1932; Kubik 1968, 1988），類型論（Jones 1959; Nketia 1974），構成 原理に関する理論（Blacking 1967; Kubik 1986; Tsukada 1998b）などさまざまな角度から研究がなされ，その関心 は一部で今日まで続いている。楽器研究も 30 年代のホル ンボステルの論文 (Hornbostel, 1933) 以降, 本格化した。 1965年に出版されたガスキンの『アフリカ音楽文献目録』 （Gaskin, 1965）では，アフリカの楽器に関した資料が全 3370編のうち 768編を占める（Nketia, 1998: 49)。20世紀 前半に関心がかなり楽器に注がれていたことがわかる。 これらの音楽分析と楽器研究はいずれも西洋芸術音楽を 主な研究対象とする近代音楽学の学的関心と傾向をその まま反映したものであるが，一方アフリカ研究に固有の 領域として発達したものに音楽のフィールド・ドキュメ ンテーションがある。

この分野の先駆者として知られているのは，南アフリ カで活動したイギリスの音楽研究者兼蒐集家ヒュー・卜 レイシー（Hugh Tracey）である。彼は 1948 年から 20 年以 上大陸の中部, 東部, 南部を広範囲に録音調查し, 後に 膨大な音楽資料を公にした（Tracey, 1973）。またそのよう
な収集活動と同時に，40年代から50年代にかけてアフリ 力音楽学会 (African Music Society) および国際アフリカ 音楽資料館（International Library of African Music）を創設 し，さらに学術誌『アフリカ音楽』(African Music) を定 期的に刊行して, 南アフリカをアフリカ音楽研究の拠点 の一つとした。ここからブラッキングやクービックなど アフリカ音楽研究の後の指導者たちが育っていることを みても, 当時南アフリカが学術的にかなり重要な拠点だ ったことがわかる。

\section{3. アフリカン・ポップス研究の背景}

さて, 1964 年にメリアムが『音楽人類学』(Merriam, 1964）の中で「文化的所産としての音楽」概念を提唱し， 音楽に対する文化人類学的アプローチの重要性を主張し た頃から，ほかの地域研究と同様，アフリカ音楽研究の あり方もしだいにシフトし始める。すなわち，主要な関 心が前述したような音の構造や組織の問題から音楽の社 会的機能や儀礼における音楽の運用法，あるいは社会構 造と音楽との関わりなど, より一般的で, 音楽と音楽外 的要素との関係性を問う問題へと移行する。たとえば， ゼンプはコートジボアールのダンの研究において音楽の 概念化や音楽家の社会的地位などの問題を通して音楽の 文化的社会的脈絡の重要性を明らかにしたし（Zemp, 1971)，またケイルは,ナイジェリアのティブの音楽に関 する言説分析をもとに音楽舞踊とほかの文化的表現との 間に共通した象徴パターンを見出し，そこからティブの 世界観を導き出している（Keil, 1979）。しかしながら，こ のような音楽文化へのアプローチの変化は 70 年代までは なお緩慢であり，研究の状況が大きく様変わりするのは 80 年代に入ってからである。

80 年代前半から今日に至るまでのアフリカ音楽研究の 状況は, 相互に関連する三つの傾向によって特徴づける ことができる。一つは, 従来の固定した「伝統」概念か ら離れて，脱植民地化やグローバル化など今日的な状況 の下での「伝統」の変容の問題に焦点を当てた研究が台 頭してきたことである。それと関連して二つ目には，従 来「ハイブリッド」なものとして敬遠されがちであった 都市の音楽文化への関心が急速に高まってきたことが挙 げられる。そしてそうした新しい傾向の延長線上にある ものとして，あるいはその飛躍的な展開として，三つ目 に今日の「アフリカン・ポップス」占に関する研究の隆盛 がある。もちろん，これら諸傾向は 80 年代に突然現れた わけではなく，その兆候は既に 50 年代に見られた。ザン ビア中部の都市で発展したカレラ舞踊に関するミッチェ 
ルの社会人類学的研究（Mitchell, 1956）はこの分野での 先駆的な試みで，当時のアフリカ音楽研究者にかなりの 影響を与えた。ンケティアやライクロフトの初期の論文 がそれを物語る（Nketia 1957; Rycroft 1959）。そして70年 代になると，アフリカの都市音楽に関する研究はかなり 蓄積されて（Ames, 1970; Coplan, 1979; Kauffman, 1972; Ware, 1978)，80年代初頭から始まるポピュラー音楽研究 の台頭を予告する。

70 年代から 80 年代にかけてのこのような状況の変化の 背景には，アールマンが指摘するように（Erlmann， 1993:3-4），単なる研究対象の転換という以上に，この研 究分野自身の理論的方法論的な前提に対する根本的な問 い直しがあった。すなわち，社会科学一般の理論的な深 化に呼応する形で，民族音楽学者の間にも本質主義的な 「伝統」概念や「文化」概念に対する批判と反省が広がっ た。それと同時に，現代社会を特徴づけていると言って もよい音楽の商品化や音楽産業の及ぼす影響が彼らの調 査地域でも無視できない現象となって現れ，彼らの研究 においてもそれに理論的方法論的に対処する必要が生じ た。さらに付け加えれば，80年代半ばから始まったいわ ゆる「ワールド・ミュージック」の世界的なブームが研 究者に与えたインパクトも無視することはできない。も ちろん, 年代的にはアフリカのポピュラー音楽研究の台 頭はワールド・ミュージック・ブームの始まりより 5 年 近く先んじているけれども，ブームに呼応するようにし て出版されたネトルやマニュエルの著作（Nettl, 1985; Manuel, 1988）からの影響もあり，またジャーナリズムか らの要請もあって, この時期にアフリカ音楽研究者の多 くが直接間接にポピュラー音楽に関わる状況が生まれた。 そして 90 年代にはいると，「ワールド・ミュージック」 をテーマにした国際学会のシンポジウムや学術誌の特集 が組まれ，その中でアフリカン・ポップスは音楽研究者 の主要な関心事の一つになっていった6)。

\section{4. 社会史としてのポップス研究}

さて，この時代的ブームに呼応して 80 年代半ばから 90 年代前半までに出版されたアフリカン・ポップスに関す る著書・論文はかなりの数に上るが, その初期の研究書 の中で注目に值するのは，西アフリカのポピュラー音楽 を論に゙たコリンズと南アフリカの黒人都市音楽を扱った コプランの研究である (Collins, 1985; Coplan, 1985)。これ らを含めて，それ以後影響力のあったこの分野の著書一 たとえば, 南アフリカの黒人ポピュラー音楽に関するア ールマンの研究 (Erlmann, 1991)，あるいはナイジェリア
のジュジュに関するウォーターマンの研究（Waterman, 1990）一に共通した特徵は，それらが音の形式分析から ほとんど完全に離れて音楽の社会史研究になっていると いう点である。たとえば，コプランは，アパルトへイト 時代の南アフリカにおいて階級の形成や工業化の進展に 伴って成立した黒人都市文化の中で，クウェラなどの新 しい音楽様式が文化的シンボルとしてどのように発展し ていったかを明らかにしている。またウォーターマンは， ジュジュの成立発展史を記述する中で, この音楽ジャン ルがヨルバ労働者の階級意識とアイデンティティの形成 過程にいかに深く関わっていたかを示した。

このような音楽社会史としてのポピュラー音楽研究の ほか，最近の特筆すべき傾向として，この同じ分野の現 象をグローバル化やナショナリズムの視点から捉え直そ うとする動きが出ていることが挙げられる。アールマン は近著において, グローバル化現象の一つとして南アフ リカの人気グループ，レディスミス・ブラック・マンバ 一ゾの欧米音楽産業への関わりを取り上げ，それを一世 紀前の南アフリカ黒人合唱団の欧米公演と比較しながら， アフリカと欧米双方における近代的アイデンティティの 形成に関わる諸問題を論じている（Erlmann, 1999）。また トゥリノは，解放闘争を通じて発展したジンバブエのポ ップス, チムレンガが一方でどのようにジンバブエのナ ショナリズムを表現しつつ, 他方で「ワールド・ミュー ジック」という世界市場と結びついていったかを検討し， ローカルとグローバルな文化のダイナミックな相互関係 を明らかにした (Turino, 2000)。

さて，アフリカン・ポップスの研究と並んで，80年代 後半以降のもう一つの流れは一もっとも，これはポピュ ラー音楽研究ほど大きな流れではない一, 脱植民地状況 下での音楽文化の変容に関する研究である。ここでは当 然のことながら, 独立後のナショナル・アイデンティテ 1の形成や国民文化の創出といったことと関連して音楽 文化が論じられることが多い。またこのような視点は， 前述のトゥリノの研究が示唆するように, ポピュラー音 楽研究にも多かれ少なかれ内包されていたものである。 たとえば，ケマーは植民地時代から独立達成にいたるジ ンバブエの社会史を検討する中で，独立運動が激化し， ナショナリズムが高揚するに従ってそれまで衰退してい た伝統的な楽器やジャンルが復活し, 解放闘争に関連し た新しい様式のポピュラー音楽が誕生した過程を描き出 している（Kaemmer, 1989）。またクレイトンは独立後の ガーナを事例に，新生国家のナショナル・アイデンティ ティ構築の過程で音楽と舞踊がいかに重要な役割を果た したかを明らかにした (Creighton, 1999)。一方, 西洋の 楽器であるギターが独立前後の 50 年代, 60 年代にいくつ 
かの国でナショナル・アイデンティティのシンボルとし て政治的指導者によって積極的に利用されたことを示す 研究もある (Schmidt, 1994)。

80 年代後半から今日にいたるアフリカ音楽研究は, こ のようにポピュラー音楽の社会史を中心に, 今日のグロ ーバル化の現象や独立後のナショナリズム推進の過程を 視野に入れたさまざまな音楽の変容の問題に主要な関心 が注がれてきたと言えよう7)。

本特集の最初の三編の論文 (塚田, 鶴田，鈴木論文) は, いずれも今述べたアフリカ音楽に関する最近の学的 関心を反映したもので, 本稿で論述した研究史の先端に 位置づけることのできるものである。また最後の池谷論 文は，アフリカン・ポップスと直接的な関係はもたない が, 日本における最近の「音文化」研究の動向を伝える 事例として，本特集に加えることにした。

\section{注}

1）アフリカ音楽に関する初期の記録については，McCall (1998) に詳しい。

2) このような楽器の音を言語音で表す伝承法 (ないし記憶法) は、これまで nonsense syllables, oral mnemonics, oral notation, solfege, また日本語では「唱歌」（あるいは「口唱歌」）,「声の 記譜法」などとさまざまな名称で呼ばれてきた。 Trommelsilben (drum syllables)はべッツの用語法である。本稿で は以後この種の音楽伝承法を「口唱歌」と呼ぶことにする。

3）日本におけるアフリカ「音文化」研究の最近の成果としては, Kawada (1997)及び Kawada et Tsukada (2001)を参照。

4)「ハーモニー」という西洋音楽の用語をそのままアフリカ音 楽に適用することには問題がある。そのため，カウフマンら は「多声部組織」(multi-part organization) というより中立的な 語を用いるべきだと主張する（Kauffmann, 1984）。しかしなが ら，実際にはより適切な用語がないこともあり，今日でも 「ハーモニー」という語はアフリカ音楽に対して広く用いられ ている。したがって，本稿でも従来の用語法に従うこととす る。

5）「アフリカン・ポップス」という語は，1980年代半ばの「ワ ールド・ミュージック」ブームの際にジャーナリズムの世界 で用いられた用語で，とくにパパ・ウェンバやサリフ・ケイ タなど，当時マスコミで注目を集めたアフリカのポピュラ 一・ミュージシャンの音楽を指して使用された言葉である。 しかし本稿ではこれを, 最も広い意味での「アフリカのポピ ュラー音楽」の別称として用いることにする。なお，ポピュ ラー音楽を本稿では「芸術音楽，民俗音楽に対する一区分と して,メディアや音楽産業などと深く結びつき，大衆文化に 根ざした音楽のカテゴリー」と定義する。

6) 民族音楽学関係の重要な学術誌『音楽の世界』(The World of Music)では, 1993 年第 35 巻 2 号に「「ワールド・ミュージック』 の政治と美学」(The Politics and Aesthetics of "World Music") と 題する特集が組まれた（Erlmann \& Hernandez, 1993）。
7）アフリカ音楽研究の最先端で今日問題になっているテーマと しては，このほかに音楽産業と関連して音楽著作権の問題， アフリカ音楽の教育システム構築の問題, 観光開発の問題, 音楽検閲の問題，などがあるが，本特集と必ずしも直接的な 関係を持たないため，本稿ではその紹介を割愛した。

\section{参考文献}

Agawu, K., (1995) African Rhythm: A Northern Ewe Perspective, Cambridge, Cambridge University Press.

Ames, D., (1970) "Urban Hausa Music," African Urban Notes, 5(4): 1924.

Arom, S., (1991) African Polyphony and Polyrhythm: Musical Structure and Methodology, Cambridge, Cambridge University Press.

Betz, R., (1976 [1898]) "Die Trommelsprache der Duala," in Th.Sebeok \& D.Umiker-Sebeok(eds), Speech Surrogates, Drum and Whistle System, The Hague, Mouton, pp.158-258.

Blacking, J., (1955) "Some Notes on a Theory of African Rhythm Advanced by Erich von Hornbostel," African Music, 1(2): 12-20.

Blacking, J., (1967) Venda Children's Songs, Johannesburg, Witwatersrand University Press.

Buckner, M., (1998) "Functions of Song in Zande 'Chantefables,"' Paper presented to the 43rd Annual Meeting of the Society for Ethnomusicology, Bloomington, Indiana, 21-25 October.

Carrington, J.F., (1949) Talking Drums of Africa. London, Carey Kingsgate Press.

Chernoff, J. M., (1979) African Rhythm and African Sensibility: Aesthetics and Social Action in African Musical Idioms, Chicago, University of Chicago Press.

Collins, J., (1985) African Pop Roots, London, W.Foulsham.

Coplan, D., (1979) "The African Musician and the Development of the Johannesburg Entertainment Industry, 1900-1960," Journal of Southern African Studies, 5 (2): 134-164.

Coplan, D., (1985) In Township Tonight: South Africa's Black City Music and Theatre, Johannesburg, Ravan Press.

Creighton, L., (1999) "The Ghana Dance Ensemble: Music, Dance and the Construction of Post-Colonial National Identity," Paper presented to the 44th Annual Meeting of the Society for Ethnomusicology, Austin, 1821 November.

Erlmann, V., (1991) African Stars: Studies in Black South African Performance, Chicago, University of Chicago Press.

Erlmann, V., (1993) "The Politics and Aesthetics of Transnational Musics," The World of Music, 35(2): 3-15.

Erlmann, V., (1999) Music, Modernity, and the Global Imagination: South Africa and the West, Oxford, Oxford University Press.

Erlmann, V. \& Hernandez, D. P.,(eds), (1993) Special Issue "The Politics and Aesthetics of 'World Music,"' The World of Music, 35(2).

Gaskin, L., (1965) A Select Bibliography of Music in Africa, London, International African Institute.

Hornbostel, E. von, (1928) "African Negro Music," Africa, 1: 30-62.

Hornbostel, E. von, (1933) "The Ethnology of African Sound Instruments," Africa, 6: 129-154, 277-311.

Hughes, D., (1989) "The Historical Uses of Nonsense: Vowel-Pitch 
Solfege from Scotland to Japan," in M. L. Philipp (ed.), Ethnomusicology and the Historical Dimension, Beuzlen, Philipp Verlag, pp.3-18.

Jones, A. M., (1934) "African Drumming," Bantu Studies, 8: 1-16.

Jones, A. M., (1959) Studies in African Music, 2 vols, London, Oxford University Press.

Kaemmer, J., (1989) "Social Power and Music Change Among the Shona," Ethnomusicology, 33(1): 31-45.

Kauffman, R., (1972) "Shona Urban Music and the Problem of Acculturation," Yearbook of the International Folk Music Council, 4: 47-56.

Kauffman, R., (1980) "African Rhythm: A Reassessment," Ethnomusicology, 24(3): 393-415.

Kauffman, R., (1984) "Multipart Relationships in Shona Vocal Music," in J.H.K.Nketia and J.C.Djedje (eds), Selected Reports in Ethnomusicology 5: Studies in African Music, Los Angeles, Program in Ethnomusicology, University of California, pp.145159.

川田順造，(1982）レコード『サバンナの音の世界』解説書付き， 東芝EMI, TWX-90173 74.

川田順造，(1983）「口頭伝承論 1 一音のコミュニケーションの 諸相」川田順造他編「社会史研究 $2 』$ 日本エディタースクー ル出版部, pp.1-133.

川田順造，(1984）「口頭伝承論 2一音のコミュニケーションの 諸相」川田順造他編『社会史研究 $5 』$ 日本エディタースクー 儿出版部, pp.149-194.

Kawada, J.,(ed.), (1997) Cultures sonores d'Afrique, Tokyo, Institute for the Study of Languages and Cultures of Asia and Africa, Tokyo University of Foreign Studies.

Kawada, J. et Tsukada, K.,(eds), (2001) Cultures sonores d'Afrique II -Aspects dynamiques-, Hiroshima, Hiroshima City University.

Keil, Ch., (1979) Tiv Song, Chicago, University of Chicago Press.

Kirby, P., (1932) "The Recognition and Practical Use of the Harmonics of Stretched Strings by the Bantu of South Africa," Bantu Studies, 6(1): 30-46.

Klassen, D., (1998) "And Then It Went Zi-I: Verbal-Gestural Iconicity in Shona Cante Fable Performance," Paper presented to the 43rd Annual Meeting of the Society for Ethnomusicology, Bloomington, Indiana, 21-25 October.

Kubik, G., (1968) Mehrstimmigkeit und Tonsysteme in Zentral- und Ostafrika, Wien, Hermann Böhlaus Nachf.

Kubik, G., (1986) "A Structural Examination of Homophonic MultiPart Singing in East and Central Africa," Anuario Musical, 39/40 27-58.

Kubik, G., (1988) "Nsenga/Shona Harmonic Patterns and the San Heritage in Southern Africa," Ethnomusicology, 32(2): 39-76.

McCall, J., (1998) "The Representation of African Music in Early Documents," In R.Stone (ed.), The Garland Encyclopedia of World Music: Africa, New York, Garland, pp.74-99.

Manuel, P., (1988) Popular Musics of the Non-Western World: An Introductory Survey, Oxford, Oxford University Press. (マニュエ ル, P. [中村とうよう訳], 1992. 非西欧世界のポピュラー音楽』 ミュージック・マガジン).

Merriam, A., (1964) The Anthropology of Music, Evanston, Northwestern University Press. (メリアム, A. [藤井知昭, 鈴木道子訳],
1980.『音楽人類学』音楽之友社).

Mitchell, C., (1956) The Kalela Dance, Rhodes-Livingstone Papers no.27, Manchester, Manchester University Press.

Neeley, P., (1999) People of the Drum of God-Come! Dallas, SIL International.

Nekes, P.H., (1976 [1912]) "Trommelsprache und Fernruf bei den Jaunde und Duala in Südkamerun," in Th.Sebeok \& D.UmikerSebeok(eds), Speech Surrogates: Drum and Whistle System, The Hague, Mouton, pp.289-306.

Nettl, B., (1985) The Western Impact on World Music: Change, Adaptation, and Survival, New York, Schirmer Books. (ネトル, B. [細川周平訳], 1989. 『世界音楽の時代』勁草書房).

Nketia, J. H. K., (1957) "Modern Trends in Ghana Music," African Music, 1(4): 13-17.

Nketia, J. H. K., (1974) The Music of Africa, New York, Norton. (ンケ ティア，K. [龍村あや子訳]1989.『アフリカ音楽』晶文社).

Nketia, J. H. K., (1998) "The Scholarly Study of African Music: A Historical Review," in R.Stone (ed.), The Garland Encyclopedia of World Music: Africa, New York, Garland, pp.13-73.

Reily, S.A., (1998) "Venda Girls' Initiation Schools Revisited: A Dialogue with John Blacking," Paper presented to the 43rd Annual Meeting of the Society for Ethnomusicology, Bloomington, Indiana, 21-25 October.

Rycroft, D., (1959) "African Music in Johannesburg: African and nonAfrican features," Journal of the International Folk Music Council, 11: 25-30.

Schmidt, C., (1994) "The Guitar in Africa: Issues and Research," The World of Music, 36(2): 3-20.

Temperley, D., (2000) "Meter and Grouping in African Music: A View from Music Theory," Ethnomusicology, 44(1): 65-96.

Tracey, H., (1973) Catalogue: the Sound of Africa Series: 210 Long Play Records of Music and Songs from Central, Eastern, and Southern Africa, 2 vols, Roodepoort, South Africa, International Library of African Music.

Tsukada, K., (1998a) "Drumming and Sound Symbolism Among the Luvale of Zambia," Paper presented to the 43rd Annual Meeting of the Society for Ethnomusicology, Bloomington, Indiana, 21-25 October.

Tsukada, K., (1998b) "Harmony in Luvale Music of Zambia," in R.Stone (ed.), The Garland Encyclopedia of World Music: Africa, New York, Garland, pp.722-743.

Turino, Th., (2000) Nationalists, Cosmopolitans, and Popular Music in Zimbabwe, Chicago, University of Chicago Press.

Ware, N., (1978) "Popular Music and African Identity in Freetown, Sierra Leone," in B.Nettl (ed.), Eight Urban Musical Cultures: Tradition and Change; Urbana, Univeristy of Illinois Press, pp.296-320.

Waterman, Ch., (1990) Jùjú: A Social History and Ethnography of an African Popular Music, Chicago, University of Chicago Press.

Zemp, H., (1971) Musique Dan: La musique dans la pensée et la vie sociale d'une société africaine, Paris, La Haye, Mouton. 